\title{
The Balance of Payments and Russian Economic Growth
}

\section{Edgar Demetrio Tovar-García ${ }^{1}$, Carlos A. Carrasco ${ }^{2}$}

\author{
1 Universidad Panamericana. Escuela de Ciencias Económicas y Empresariales, \\ Prolongación Calzada Circunvalación Poniente 49, Zapopan, Jalisco, 45010, México. \\ E-mail: demetrio.tovar@gmail.com \\ 2 Universidad de Monterrey, \\ Av. Ignacio Morones Prieto 4500 Pte., San Pedro Garza García, N.L. México, 66238. \\ E-mail: carlos.carrasco@udem.edu
}

Based on a demand-side approach, Thirlwall's law claims that, in the long-run, economic growth is constrained by the balance of payments. Income elasticity of demand for exports should be greater than income elasticity of demand for imports in order to grow faster than the limit imposed by export demand. Accordingly, accurate estimations of income elasticities are necessary to identify these bounds. This research estimates export and import functions using bilateral trade data between Russia and 53 of its major partners. Then, we empirically test the validity of Thirlwall's law over the years 1996-2016, generalizing Thirlwall's model in a bilateral panel framework. In addition, export and import functions are estimated taking into account export and import composition, controlling for key sectoral effects on aggregate elasticities. Using dynamic panel data models, the findings suggest that, on average, the Russian economy has been growing faster than what Thirlwall's law predicts. The sectoral composition of the Russian external sector has eased the external constraint to growth. Russian exports still significantly consist of oil and gas, price inelastic goods, with positive effects on trade balance over the period of study. However, in a transition toward green energies, the allocation and investment of exports revenues is a key factor to address future scenarios where carbon-based resources lose relevance.

Key words: balance-of-payments constrained growth; export function; import function; economic growth; Russia.

JEL Classification: F14, F43, 049.

DOI: $10.17323 / 1813-8691-2019-23-4-524-541$

Edgar Demetrio Tovar-García - Ph.D. in Economics, Research Professor, Universidad Panamericana. Escuela de Ciencias Económicas y Empresariales.

Carlos A. Carrasco - Associate Professor, Universidad de Monterrey.

The article was received: 28.08.2019/The article is accepted for publication: 20.11.2019. 
For citation: Edgar Demetrio Tovar-García, Carlos A. Carrasco. The Balance of Payments and Russian Economic Growth. HSE Economic Journal. 2019; 23(4): 524-541.

\section{Introduction}

After perestroika, the Russian economy has been presenting relatively high economic growth rates, 3,1\% on average from 1996 to 2016. The average GDP growth rate equals 5,3\% excluding the crisis years: 1996 (the last year of the long period of economic contraction after the dissolution of the Soviet Union), 1998 (financial crisis), 2009 (the global financial crisis), and 2015-2016 (the Ukrainian crisis and western sanctions). The average rate was 6,9\% considering only the period 1999-2008. Therefore, the Russian average growth rate has been higher than in several Latin American countries, but lower than in some Asian countries. However, it is important to note that Russia showed economic growth rates similar to those reached in China or India in the early 2000s.

At the same time, the Russian economy was opening up to the western world. Over the years 1996-2016, trade openness was 53,7\% (exports plus imports as percentage of GDP). However, in the last years, trade openness has been presenting a negative trend (46\% in 2016), accompanied by several economic and political measures (economic sanctions and trade restrictions introduced by a number of Western countries) after the reunification of Crimea with Russia in 2014. In addition, it is highly interesting to note that Russia has been presenting a persistent surplus in its trade and current accounts, 8,9\% and 5,7\% of GDP, respectively, over the period 1994-2016 [Aristovnik, 2007; Navoi, 2017; Tovar-García, 2018; Tovar-García, Carrasco, 2019].

Given this, the main research objective of the present study is to determine the limits of the Russian economic growth in accordance with Thirlwall's law, a demand-side approach, where economic growth relative to open economies is restricted to the ratio between income elasticity for exports and income elasticity for imports.

Thirlwall's law has been tested in many countries [Hierro Recio, Atienza Montero, Hailer, 2018; Thirlwall, 2011]. The Russian case has been also studied in an analysis for BRICS countries, over the period 1995-2013 where Nassif, Feijo, and Araújo (2016) found that the Russian growth rate should be between $0,48 \%$ and $1,86 \%$ according to Thirlwall's law. These estimates are lower than the actual GDP growth rate of this period $(3,3 \%)$. In other words, the estimated balance of payments constrained growth rate does not agree with the actual Russian growth rate. By contrast, for the rest of BRICS countries, the estimated balance of payments constrained growth rates are good predictors of actual growth rates [Britto, McCombie, 2009; Jeon, 2009; Nassif et al., 2016; Razmi, 2005; Romero, Silveira, Jayme, 2011].

The inconsistences for the Russian case inspired the present research, thinking that the problem is a result of incorrect estimations of income elasticities we obtain several estimates to check the robustness of results under a bilateral framework and controlling for key sectoral effects of high-tech imports and fuel exports. In addition to specific findings for Russia, this paper contributes to the literature in two main ways. First, this research is a pioneer in the use of bilateral panel data to estimate income elasticities of demand for exports and imports, used to compute Thirlwall's growth rates. Second, to estimate export and import functions we include export and import composition to account for key sectoral effects altering price and income elasticities. 
Previous analyses of Thirlwall's law have highlighted the role of high-tech industries in the balance of payments constraint, the findings suggest that high-tech goods have higher income-elasticities and promote economic growth [Araujo, Lima, 2007; Gouvea, Lima, 2010; Romero et al., 2011]. Whilst other articles point out the price inelastic nature of petroleum and natural gas, a key component of Russian exports [Cooper, 2003; Krichene, 2002; Tovar-García, 2018]. Therefore, trade composition may affect price and income elasticities in both export and import functions. However, there is no examination of the role of export and import composition in a bilateral framework estimating Thirlwall's law. For the first time, this article estimates income elasticities, the main input to compute the balance of payments constrained growth rates, taking into account trade composition. Thus, this study extends previous works on the Thirlwall's law using a multilateral approach (bilateral data) and adding key sectoral effects (trade composition) in the econometric specification for estimations of export and import functions.

The rest of this paper is structured as follows. In the second section, we present a brief synthesis of the recent developments of the Russian economy, with special focus on economic growth and external sector performance. This section also highlights the Thirlwall's law, setting out the basis for the empirical analysis. In the third section, we explain the empirical strategy and the method of estimation. Section 4 presents the main results. Finally, in the fifth section, we draw main conclusions and some policy implications.

\section{Russian growth, external sector performance and Thirlwall's law}

\subsection{The Russian economy}

Starting with perestroika, the Russian economy has been involved in a deep process of reform and restructuring, including key modifications in the external sector to open the economy. Figure 1 shows some key variables related to the process of trade opening. It is easy to observe that the trade openness of Russia has been increasing since the 1990's, reaching a peak in the 2000's, with a slightly decreasing trend in the 2010's. Data unavailability do not allow making deeper comparisons with previous periods, but it is well known that international trade in the Soviet time was dominated by political reasons.

In this regard, both, the current account and the trade balance have been presenting persistent surpluses. The surplus peak was reached in 2000 and the positive balance has been decreasing but remaining thereafter. Note that there is no clear downward trend in the international trade costs of the Russian economy with its top trade partners. That is, unlike other transition countries, the recent performance of the Russian external sector does not necessarily reflect a decrease in the cost associated to international transactions.

The presence of persistent relatively high surpluses in trade and current accounts has coincided with a period of high economic growth, yet with economic crises (see Figure 2). For instance, on average for the period 1999-2017, GDP growth and GDP per capita growth were $3,98 \%$ and $4,02 \%$, respectively (in Figure $2 \mathrm{a}$, they are practically overlapped). Even more, excluding the year 2009 (global financial crisis) the average growth rates were 4,64\% and 4,68\%, respectively. 


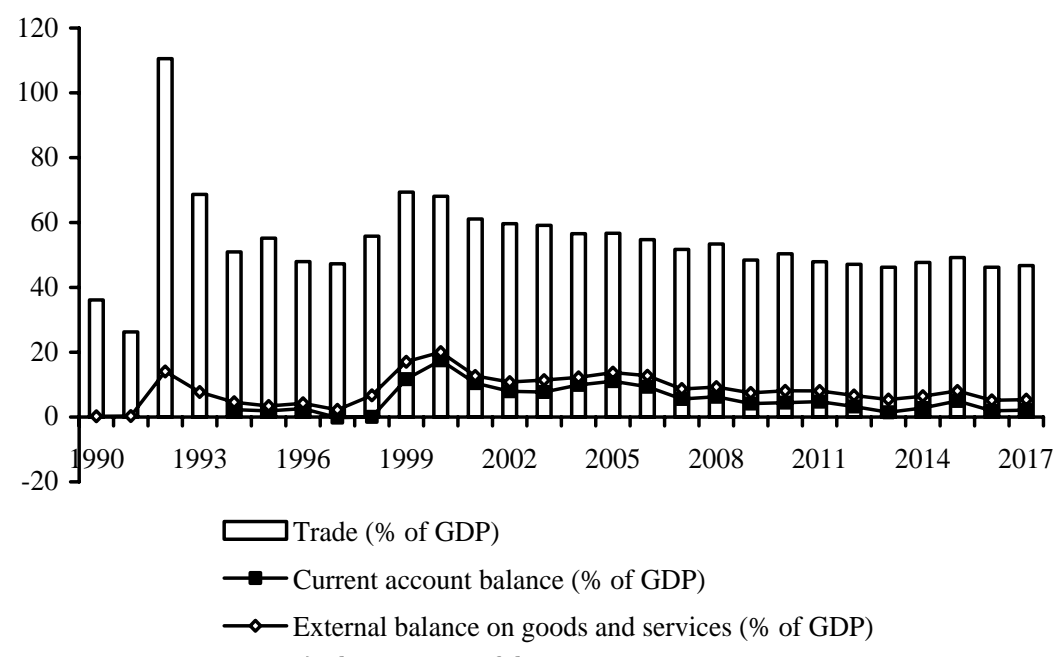

a) The opening of the Russian economy

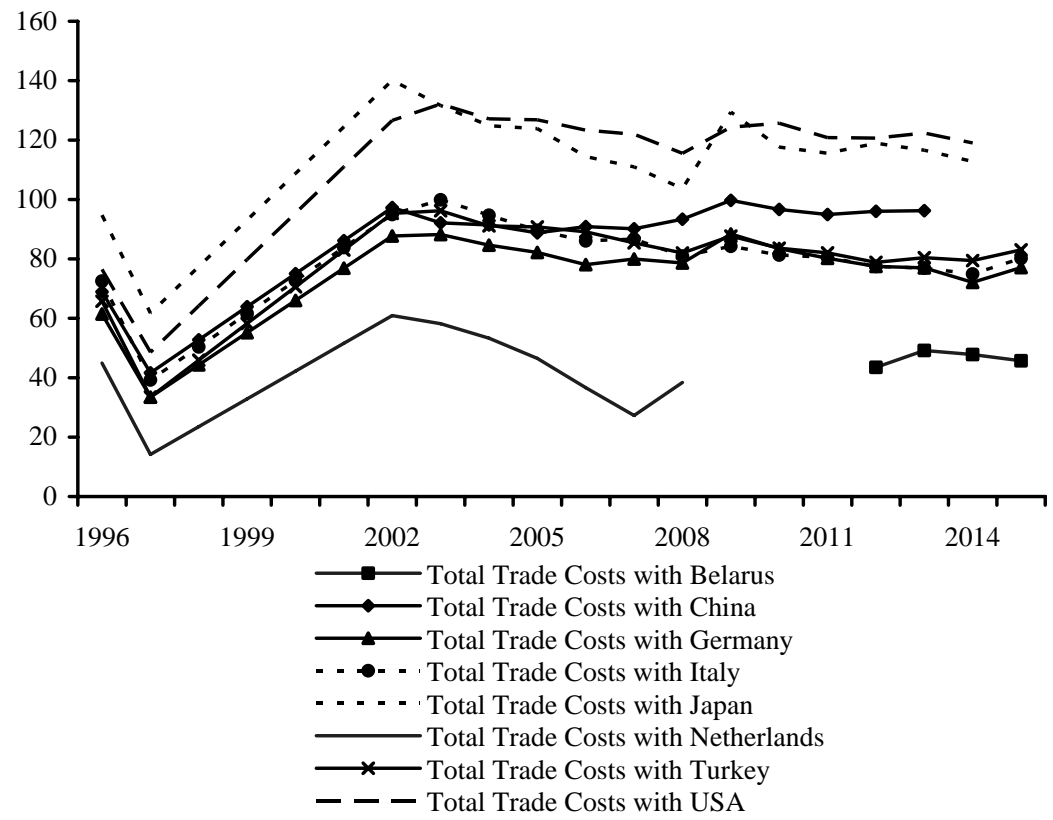

b) Trade Costs with Top Trade Partners

Fig. 1. The opening of the Russian economy

Source: World Development Indicators and ESCAP International Trade Costs.

Thus, the Russian economy has maintained a significant growth rate while, at the same time, presents a persistent surplus in trade and current accounts. In theory, if an economy grows, the effect on imports of the increase in income will generate a worsening of the trade 
balance, ceteris paribus. However, the effect will depend on different factors. On the one hand, it is important to recognize what factors have generated an increase in exports and how this increase affects domestic and external consumption. Note that the years of the persistent external surpluses are characterized by an improvement in the Russian terms of trade, in a context of growing global demand after the insertion of China and other developing countries in the world economy.

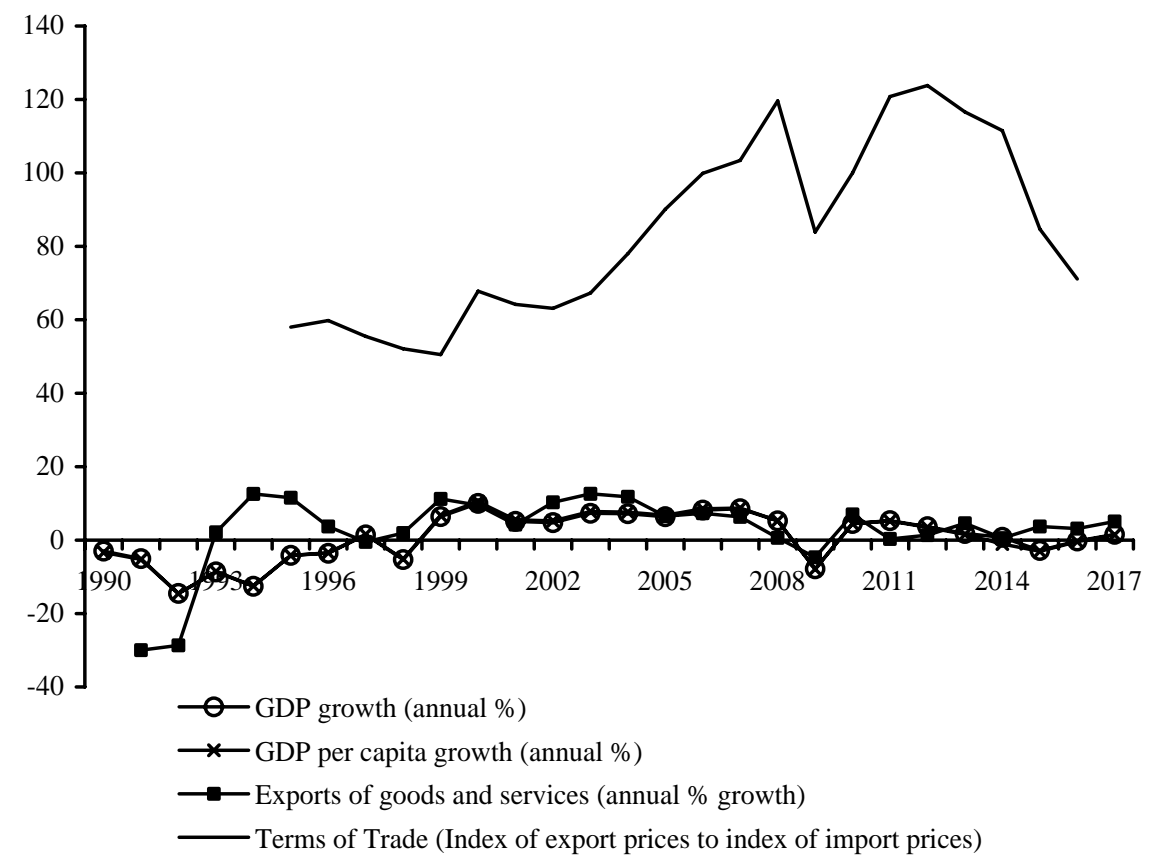

a) GDP, GDP per capita, exports and terms of trade

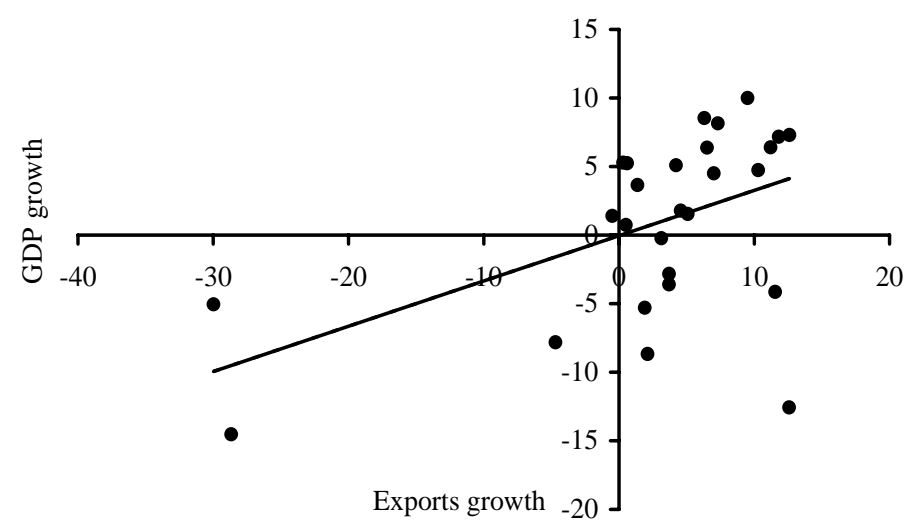

b) GDP growth and exports growth

Fig. 2. Growth, exports and terms of trade

Source: World Development Indicators and OECD stats. 
On the other hand, the effects of an increase in economic growth on the trade balance depend on how imports respond to changes in income, that is, income elasticity of demand for imports. In this regard, export and import composition turns crucial since both facts help to determine the effects of increasing income on external balances. Figure 3 shows the evolution of export and import composition for the Russian economy. Note the relevance of fuel exports in total merchandise exports, although this relevance has been decreasing since 2014 as a share of merchandise exports and as a share of total exports since the last decade. On average, the share of fuel exports accounts for $57,6 \%$ of total merchandise exports over the period 19962017. Previous studies have highlighted that petroleum and natural gas are largely inelastic to price variations, due to its relevance for the functioning of the world economy, especially in a moment of growing global demand [Cooper, 2003; Krichene, 2002; Tovar-García, 2018]. Furthermore, imports of manufactures are the main component of merchandise imports: the share of manufactured imports accounts for $69,7 \%$ of merchandise imports during the period 19962017. In this regard, a recent investigation shows the relevance of high-tech imports as a determinant of the Russian trade balance. High-tech goods, with a high added value, are income elastic and price inelastic, and a significant share of this kind of goods in total imports is negative linked to trade balance [Tovar-García, Carrasco, 2019].

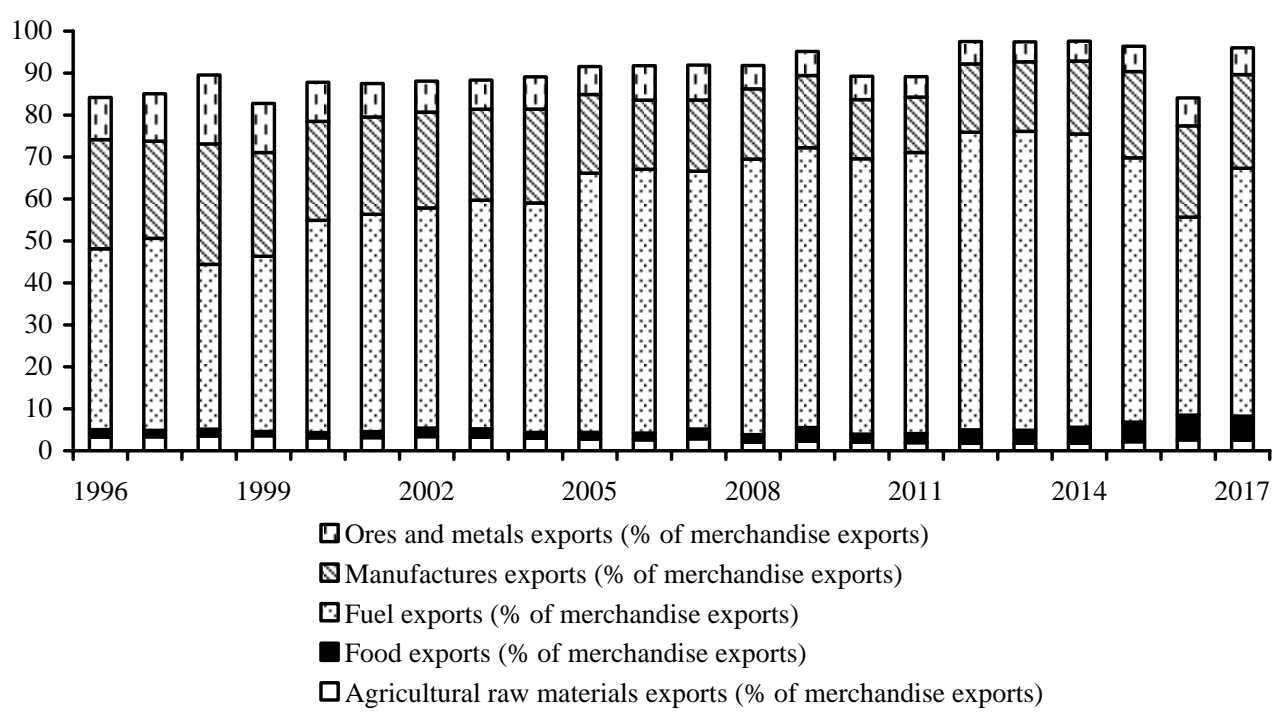

a) Export composition 


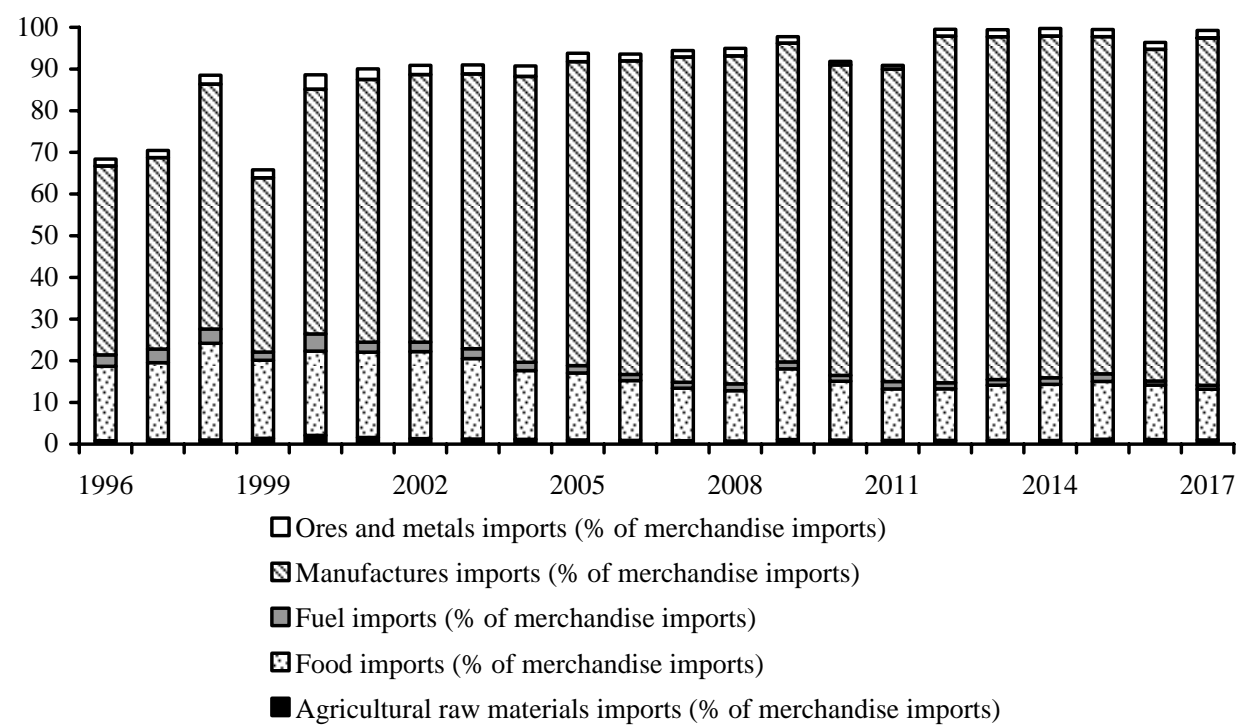

b) Import composition

Fig. 3. Export and import composition

Source: World Development Indicators.

\subsection{Thirlwall's law and its empirical specification}

In last 40 years, there has been a worldwide adoption of export-led growth strategies; Russia has not been the exception. In general terms, defenders of export-led growth strategies highlight several benefits [Palley, 2012]. First, given relative differences in the production of goods and services, according to the comparative advantage theory, there will be gains from specialization and trade [Appleyard, Field, 2014]. Second, the implementation of export-led growth strategies has forced the adoption of sound practices in business restricting rent-seeking activities and increasing competence for domestic producers. Third, open economies have benefited from technological diffusion, especially through foreign direct investment [Grossman, Helpman, 1990]. Finally, from a Keynesian perspective, there are gains in a context of a multiplier with foreign repercussions [Appleyard, Field, 2014].

Thus, in an open economy, the conditions for economic growth differ from those in a closed economy. In this regard, there have been several attempts to analyze the determinants of growth in an open economy [Greenaway, Morgan, Wright, 2002; Grossman, Helpman, 1990, 1991; Rebelo, 1992; Sachs, Warner, 1995; Thirlwall, 1979, 2011; Thirlwall, Hussain, 1982; Wacziarg, Welch, 2008]. However, many of the existing researches have come from a neoclassical viewpoint where supply side is the main (and only) determinant of the rate of growth of an economy through supply factors and productivity (mainly in the long-term).

In this regard, Anthony Thirlwall was a pioneer in introducing a framework to explore the determinants of growth from a Keynesian demand-side perspective. Thirlwall developed a model explaining differences in the growth rate of open economies where the main economic 
growth constraint is found in the balance of payments in what is known as the balance of payments equilibrium growth rate [Thirlwall, 1979, 2011; Thirlwall, Hussain, 1982]. Starting with Equation (1), the current account equilibrium is expressed as:

$$
P_{d t} X_{t}=P_{f t} M_{t} E_{t} .
$$

Given standard export and import functions, Equations (2) and (3):

$$
\begin{aligned}
& X_{t}=a\left(\frac{P_{d t}}{P_{f t} E_{t}}\right)^{\eta} Z_{t}^{\varepsilon} \quad \eta\langle 0, \varepsilon\rangle 0, \\
& M_{t}=b\left(\frac{P_{f t} E_{t}}{P_{d t}}\right)^{\psi} Y_{t}^{\pi} \quad \psi\langle 0, \pi\rangle 0,
\end{aligned}
$$

where $X$ is real exports, $M$ is real imports, $P_{d}$ and $P_{f}$ are domestic and foreign price levels of exports and imports, respectively, $E$ is the nominal exchange rate measured as the domestic price of foreign currency, $Z$ is foreign income, $Y$ is domestic income, $\eta$ and $\psi$ are the price elasticities, $\varepsilon$ and $\pi$ are the income elasticities of demand for exports and imports, respectively, and $t$ is time.

The dynamic form of the model (using growth rates) is obtained taking logarithms and differentiating with respect to time, as expressed in Equations (4) through (6).

$$
\begin{aligned}
& p_{d t}+x_{t}=p_{f t}+e_{t}+m_{t}, \\
& x_{t}=\eta\left(p_{d t}-p_{f t} e_{t}\right)+\varepsilon\left(z_{t}\right), \\
& m_{t}=\psi\left(p_{f t} e_{t}-p_{f t}\right)+\pi\left(y_{t}\right) .
\end{aligned}
$$

Finally, the balance of payments equilibrium growth rate, given in Equation (7), is obtained plugging Equations (5) and (6) into Equation (4).

$$
y_{t}=\frac{\left[(1+\eta+\pi)+\left(p_{d t}-p_{f t}-e_{t}\right)\right] \psi+\varepsilon\left(z_{t}\right)}{\pi} .
$$

Thirlwall's law highlights the role of exports as the main demand component causing economic growth because of two facts. First, exports dynamize other components of the aggregate demand. Second, the balance of payment constraint to growth is relaxed with increases in exports [Clavijo-Cortes, Ros-Bosch, 2015]. According to Thirlwall, the rate of growth of an open economy is constrained by the balance of payments. For instance, since imports are a positive function of income, the increase of imports when income grows will lead to a deterioration of the current account, ceteris paribus. If the current account deficit is persistent, external debt will increase, leading to a decrease in the growth capacity. Therefore, the growth rate of exports, as well as the response of imports to a change in income, are key variables in determining the long-term growth rate of the economy [Thirlwall, 1979]. 
Summarizing and simplifying, in the long-term, Thirlwall's law claims a relationship between economic growth, exports and imports, where economic growth is constrained by Equation (8), weak version, assuming that the relative prices measured in a common currency are constant, or Equation (9), strong version, assuming that relative prices changes over the long run [Thirlwall, 1979, 2011; Thirlwall, Hussain, 1982].

$$
\begin{aligned}
& y=\frac{x}{\pi}, \\
& y=\frac{\varepsilon\left(z_{t}\right)}{\pi} .
\end{aligned}
$$

\section{Empirical strategy}

\subsection{Export and import functions in a bilateral framework}

To specify the upper limit of the Russian income growth rate, in accordance with Thirlwall's law, it is necessary to find accurate estimations of income elasticities. For this reason, we firstly estimate the following augmented export and import functions for Russia, in a bilateral framework, as expressed in Equations (10) and (11).

$$
\begin{aligned}
& \ln X_{R j, t}=\beta_{0 j}+\beta_{1} \ln Y_{j t-1}+\beta_{2} \ln R E R_{R j, t-1}+\beta_{3} Z_{j t}+e_{j}+v_{j t}, \\
& \ln M_{R j, t}=\beta_{0 j}+\beta_{1} \ln Y_{R t-1}-\beta_{2} \ln R E R_{R j, t-1}+\beta_{3} Z_{j t}+e_{j}+v_{j t} .
\end{aligned}
$$

Subscripts $R, j$ and $t$ indicate Russia, partner country, and time, respectively. In indicates a logarithmic transformation of the variables, consequently, the coefficients measure elasticities. $Z$ represents control variables: export $\left(E C_{R j}\right)$ or import composition $\left(M C_{R j}\right)$, yearly oil price, time dummy variables, and dummy variables for Commonwealth of Independent States (CIS), Central Eastern European countries (CEE) and Western European countries (WEC), capturing all factors that are constant over time but specific for these groups of countries and Russia.

It is worth noticing that these models contribute to Thirlwall's law in two ways. First, our strategy uses a multilateral approach (bilateral data), that is, our estimations are not limited by variables from the rest of the world, computed as a weighted average, versus Russia. Second, our specification includes key sectoral effects on income elasticities, focusing on trade composition. Consequently, the use of bilateral trade data provides a longitudinal structure (and more observations) and the inclusion of export and import composition control for specific sectoral impacts on income elasticities, in the bilateral export and import functions. This gives a proportional relevance to the trade size of each partner and to the kind of goods that are traded.

The hypothesis states that $X_{R j}$ (real exports to partner country) depends positively upon the level of $Y_{j}$ (GDP or GDP per capita of the partner country, in constant US dollars) and $R E R_{R j}$ (real exchange rate in relation to the currency of the partner country). An increase in $R E R_{R j}$ means a depreciation of the ruble. In other words, a higher income of partner countries and a relative depreciation of the ruble should favor Russian bilateral exports $\left(X_{R j}\right)$. For its part, an increase in Russian GDP and/or a relative appreciation of the ruble should favor Russian bilateral imports, real imports from partner country $\left(M_{R j}\right)$. 
It is important to note that we are using bilateral real exports and bilateral real imports. We use the USA consumer price index $(2010=100)$ to deflate total exports and total imports in U.S. dollars, due to limitations to use other deflators, as it has been previously used in the economic literature [Micco et al., 2003; Wierts et al., 2014; Tovar-García, 2018]. Also, note that to estimate income elasticity in both functions (Equations 10 and 11) we use the log of GDP or the log of GDP per capita (to check robustness). The real exchange rate $(R E R), 1$ partner's currency to ruble, is measured multiplying the nominal exchange rate by the ratio of consumer price indexes between partner country and Russia.

Following previous analysis of Thirlwall's law [Araujo, Lima, 2007; Gouvea, Lima, 2010; Romero et al., 2011], we include export and import composition to account for key sectoral effects altering price and income elasticities, where high-tech intensity eases the balance of payment constraint. Therefore, the model includes the composition of exports and imports as key independent variables.

Additionally, previous studies in the case of Europe and in the case of Russia already showed that export composition matters. Those countries with exports consisting of high-tech products improve their export performance, because these goods present a high added value and they are income elastic and price inelastic [Wierts, Van Kerkhoff, De Haan, 2014]. In the particular case of Russia, the evidence suggests that its export composition, still consisting significantly of crude petroleum and gas (price inelastic goods), also affects export performance through effects on the price elasticity of the demand for exports [Tovar-García, 2018] while imports composed of high-tech goods worsen the trade balance [Tovar-García, Carrasco, 2019].

Therefore, we use the ratio of exports of crude petroleum and gas to total exports $\left(E C_{R j}\right)$ and the ratio between imports of high-tech goods to total imports $\left(M C_{R j}\right)$ to account for these sectoral effects. This is a forgotten issue in estimations of import demand, but we claim, as in the case of exports, that if countries are importing price inelastic, income elastic, and high added value goods, then we can expect positive effects on total imports. Moreover, this should be the case of Russia, because of the increasing trade with European countries, exporting high-tech goods.

We retrieve data from the STAN Bilateral Trade Database by Industry and End-use category (BTDIxE) since our main contribution to the empirical literature is the use of total and sectorial bilateral trade data. In addition, macroeconomic data are retrieved from World Development Indicators (WDI), International Financial Statistics (IFS), and the U.S. Energy Information Administration (EIA). Data are retrieved from international sources to increase comparability among countries. We use annual observations from 1996 to 2016 on bilateral trade between Russia and 53 of its major partners to estimate functions of demand for exports and imports as presented in Equations (10) and (11).

\subsection{Method}

First, using Im-Pesaran-Shin and Fisher-type tests for unit root [Im, Pesaran, Shin, 2003; Maddala, $\mathrm{Wu}, 1999]$, including combinations of constant and trend, we found that only the variables related to GDP are non-stationary. Therefore, it is not reasonable to use cointegration analysis to estimate export and import functions. Following Tovar-García (2018), recognizing reverse causality and autoregressive characteristics in estimations of export functions, here we use the SYS GMM method [Blundell, Bond, 1998] to estimate the coefficients in Equations (10) 
and (11). This method has rarely been used to estimate these functions, but it is highly efficient once the internal instruments, correcting for endogeneity, are validated (we use the Sargan test), and in the absence of autocorrelation of second order (we use the Arellano-Bond test). Moreover, the evidence suggests that SYS GMM shows estimates of export and import functions that are more robust than estimates from vector error correction models [Romero, McCombie, 2016].

In addition, the independent variables are entered with one lag, supporting the consistency and efficiency of the estimations under potential reverse causality concerns. Moreover, we use the estimation in two steps including a maximum of one lag of dependent and independent variables as instruments to avoid the potential problem of too many instruments [Roodman, 2009]. Note that this is a dynamic model, therefore the estimated coefficients indicate the shortterm effect, and we have to divide this coefficient by one minus the coefficient of the dependent as regressor to compute the long-term coefficient.

\section{Results}

Table 1 shows the main results of the regression analysis in the estimation of the bilateral export function. Columns (1) to (4) use the log of GDP per capita to approach income (Y) and columns (5) to (8) use the log of GDP in levels (to check robustness of results). Accordingly, we obtained eight estimates of the income elasticity of the demand for exports. Estimations in columns (1) and (5) correspond to the simplest model, without control variables. Columns (2) and (6) include dummies for regions (groups of partner countries) and columns (3) and (7) enters dummies for crisis years. Finally, the most sophisticated model, columns (4) and (8), adds to regressions the role of export composition and oil price.

The estimated income elasticities for the bilateral export function are slightly different, but all suggest that exports are inelastic to income in the short-term (an increase of 1\% in income implies and increase of less than 1\% in exports). By contrast, in the long-term, the estimates suggest that exports are elastic to income, but the estimated elasticities are not very high; most of them suggest a figure slightly greater than 1 . To estimate the growth rates of Thirlwall's law, we use the long-term estimations of income elasticity, because his theory applies for the long run.

Although it is not the focus of this research, note that the regression analysis does not indicate a robust effect of exchange rate (price elasticity) on exports (in some regressions its coefficient is not statistically significant). The dummies by regions suggest that the partners of Russia are changing. Russia is exporting less to the CIS countries (the old partners from the Soviet era) in comparison with the new European partners. In addition, the results suggest that the crisis years have had a negative impact on bilateral exports, in comparison with the stable years. Finally, it is relevant to note that the inclusion of export composition in the estimations of the export function agrees with previous findings in Europe [Wierts et al., 2014] and in Russia [Tovar-García, 2018]; that is, export composition matters to explain export performance.

Similarly, Table 2 shows the main results of the regression analysis in the estimation of the bilateral import demand. In columns (1) to (4) we use the log of GDP per capita and in columns (5) to (8) we use the log of GDP. Thus, we also obtained eight estimates of the income elasticity of the demand for imports. The most sophisticated model is given in columns (4) and (8), where we include import composition (the ratio of high-tech import products to total imports) to explain import performance. 
The estimation of export function

Table 1.

Dependent variable: $\ln X$ (real exports)

\begin{tabular}{|c|c|c|c|c|c|c|c|c|}
\hline & (1) & $(2)$ & (3) & (4) & $(5)$ & $(6)$ & (7) & $(8)$ \\
\hline Lagged dependent $\left(\ln X_{R j, t-1}\right)$ & $0,91^{* * *}$ & $0,86^{* * *}$ & $0,90^{* * *}$ & $0,61^{* * *}$ & $0,90^{* * *}$ & $0,85^{* * *}$ & $0,86^{* * *}$ & $0,51^{* * *}$ \\
\hline $\begin{array}{l}\text { Partner's income } \\
\text { (ln } G D P_{j, t-1} \text { per capita) }\end{array}$ & $+0,12^{* * *}$ & $0,18^{* * *}$ & $0,24^{* * *}$ & $0,05^{*}$ & & & & \\
\hline Partner's income $\left(\ln G D P_{j, t-1}\right)$ & + & & & & $0,09^{* * *}$ & $0,17^{* * *}$ & $0,35^{* * *}$ & $0,33^{* * *}$ \\
\hline Real exchange rate $\left(\ln R E R_{R j t-1}\right)$ & $0,08^{* * *}$ & 0,0002 & $-0,04^{* *}$ & 0,01 & $0,10^{* * *}$ & $0,04^{* * *}$ & 0,02 & $0,05^{* *}$ \\
\hline Export composition $\left(\ln E C_{R j, t}\right)$ & + & & & $0,03^{* * *}$ & & & & $0,03^{* * *}$ \\
\hline CIS & & 0,06 & 0,17 & $-0,11^{* * *}$ & & $0,26^{* *}$ & $0,61^{* * *}$ & $0,64^{* *}$ \\
\hline CEE & & $0,59^{* * *}$ & $0,52^{* * *}$ & $0,31^{* * *}$ & & $0,61^{* * *}$ & $0,69^{* * *}$ & $0,43^{* *}$ \\
\hline WEC & & $0,65^{* * *}$ & $0,51^{* * *}$ & $0,81^{* * *}$ & & $0,66^{* * *}$ & $0,47^{* * *}$ & $0,41^{* * *}$ \\
\hline Oil price & & & & $0,005^{* * *}$ & & & & $0,005^{* * *}$ \\
\hline Year 1998 & & & $-0,43^{* * *}$ & $-0,15^{* * *}$ & & & $-0,39^{* * *}$ & $-0,12^{* * *}$ \\
\hline Year 2009 & & & $-0,46^{* * *}$ & $-0,32^{* * *}$ & & & $-0,47^{* * *}$ & $-0,33^{* * *}$ \\
\hline Year 2015 & & & $-0,44^{* * *}$ & $-0,25^{* * *}$ & & & $-0,46^{* * *}$ & $-0,27^{* * *}$ \\
\hline Year 2016 & & & $-0,14^{* * *}$ & $-0,04$ & & & $-0,18^{* * *}$ & $-0,12^{* * *}$ \\
\hline Constant & 0,14 & 0,04 & $-0,87^{* * *}$ & $4,87^{* * *}$ & $-1,19^{* * *}$ & $-2,68^{* * *}$ & $-7,54^{* * *}$ & $-2,09$ \\
\hline Observations & 977 & 977 & 977 & 651 & 977 & 977 & 977 & 651 \\
\hline $\mathrm{N} \times \mathrm{T}$ & $53 \times 20$ & $53 \times 20$ & $53 \times 20$ & $48 \times 20$ & $53 \times 20$ & $53 \times 20$ & $53 \times 20$ & $48 \times 20$ \\
\hline Sargan test (p-value) & $\begin{array}{r}52,92 \\
(0,55)\end{array}$ & $\begin{array}{r}52,71 \\
(0,44)\end{array}$ & $\begin{array}{r}50,50 \\
(0,53)\end{array}$ & $\begin{array}{r}42,24 \\
(0,83)\end{array}$ & $\begin{array}{r}52,98 \\
(0,55)\end{array}$ & $\begin{array}{r}52,71 \\
(0,44)\end{array}$ & $\begin{array}{r}50,71 \\
(0,52)\end{array}$ & $\begin{array}{r}41,70 \\
(0,84)\end{array}$ \\
\hline $\begin{array}{l}\text { First order serial correlation } \\
\text { test (p-value) }\end{array}$ & $\begin{array}{r}-4,15 \\
(0,00)\end{array}$ & $\begin{array}{l}-4,15 \\
(0,00)\end{array}$ & $\begin{array}{r}-3,76 \\
(0,0002)\end{array}$ & $\begin{array}{r}-4,14 \\
(0,00)\end{array}$ & $\begin{array}{l}-4,14 \\
(0,00)\end{array}$ & $\begin{array}{r}-4,15 \\
(0,00)\end{array}$ & $\begin{array}{r}-3,73 \\
(0,0002)\end{array}$ & $\begin{array}{l}-4,06 \\
(0,00)\end{array}$ \\
\hline $\begin{array}{l}\text { Second order serial correlation } \\
\text { test (p-value) }\end{array}$ & $\begin{array}{r}-1,35 \\
(0,17)\end{array}$ & $\begin{array}{r}-1,35 \\
(0,17)\end{array}$ & $\begin{array}{r}-1,32 \\
(0,18)\end{array}$ & $\begin{array}{r}0,98 \\
(0,32)\end{array}$ & $\begin{array}{r}-1,34 \\
(0,17)\end{array}$ & $\begin{array}{r}-1,35 \\
(0,17)\end{array}$ & $\begin{array}{r}-1,35 \\
(0,17)\end{array}$ & $\begin{array}{r}0,81 \\
(0,41)\end{array}$ \\
\hline \multicolumn{9}{|l|}{ Long run coefficients } \\
\hline $\begin{array}{l}\text { Partner's income }\left(\ln G D P_{j} \text { per }\right. \\
\text { capita) }\end{array}$ & 1,33 & 1,29 & 2,4 & 0,12 & & & & \\
\hline Partner's income $\left(\ln G D P_{j}\right)$ & & & & & 0,90 & 1,13 & 2,50 & 0,67 \\
\hline Real exchange rate $\left(\ln R E R_{R j}\right)$ & 0,89 & 0,001 & $-0,4$ & 0,03 & 1,00 & 0,27 & 0,14 & 0,10 \\
\hline Export composition (ln $\mathrm{EC}_{\mathrm{Rj}}$ ) & & & & 0,08 & & & & 0,06 \\
\hline
\end{tabular}

Note: $\left({ }^{*}\right)\left[{ }^{* *}\right]$ and $\left\{{ }^{* * *}\right\}$ indicate statistical significance at the $(10 \%)[5 \%]$ and $\{1 \%\}$ levels. 
The estimation of import function

Table 2.

Dependent variable: $\ln M$ (real imports)

\begin{tabular}{|c|c|c|c|c|c|c|c|c|}
\hline & (1) & (2) & (3) & (4) & (5) & (6) & (7) & $(8)$ \\
\hline Lagged dependent $\left(\ln M_{R j, t-1}\right)$ & $0,89^{* * *}$ & $0,81^{* * *}$ & $0,78^{* * *}$ & $0,81^{* * *}$ & $0,91^{* * *}$ & $0,84^{* * *}$ & $0,78^{* * *}$ & $0,82^{* * *}$ \\
\hline $\begin{array}{l}\text { Russia's income }\left(\ln G D P_{j, t-1} \text { per }\right. \\
\text { capita) }\end{array}$ & $0,31^{* * *}$ & $0,49^{* * *}$ & $0,84^{* * *}$ & $0,67^{* * *}$ & & & & \\
\hline Russia's income $\left(\ln G D P_{j, t-1}\right)$ & + & & & & $0,24^{* * *}$ & $0,40^{* * *}$ & $0,87^{* * *}$ & $0,68^{* * *}$ \\
\hline Real exchange rate $\left(\ln R E R_{R j, t-1}\right)$ & $0,12^{* * *}$ & $0,04^{* * *}$ & 0,02 & $-0,02$ & $0,12^{* * *}$ & $0,05^{* * *}$ & 0,02 & $-0,02$ \\
\hline Import composition (ln $\left.M C_{R j, t-1}\right)$ & + & & & $0,09^{* * *}$ & & & & $0,09^{* * *}$ \\
\hline CIS & & $-0,53^{* * *}$ & 0,17 & $0,20^{*}$ & & $-0,57^{* * *}$ & 0,16 & $0,18^{*}$ \\
\hline CEE & & $1,55^{* * *}$ & $2,32^{* * *}$ & $1,85^{* * *}$ & & $1,33^{* * *}$ & $2,43^{* * *}$ & $1,82^{* * *}$ \\
\hline WEC & & $1,19^{* * *}$ & $2,45^{* * *}$ & $1,85^{* * *}$ & & $1,05^{* * *}$ & $2,51^{* * *}$ & $1,83^{* * *}$ \\
\hline Year 1998 & & & $-0,25^{* * *}$ & $-0,25^{* * *}$ & & & $-0,25^{* * *}$ & $-0,26^{* * *}$ \\
\hline Year 2009 & & & $-0,55^{* * *}$ & $-0,50^{* * *}$ & & & $-0,55^{* * *}$ & $-0,51^{* * *}$ \\
\hline Year 2015 & & & $-0,77^{* * *}$ & $-0,72^{* * *}$ & & & $-0,79^{* * *}$ & $-0,73^{* * *}$ \\
\hline Year 2016 & & & $-0,39^{* * *}$ & $-0,30^{* * *}$ & & & $-0,41^{* * *}$ & $-0,31^{* * *}$ \\
\hline Constant & $-1,45^{* * *}$ & $-2,51^{* * *}$ & $-5,65^{* * *}$ & $-4,05^{* * *}$ & $-5,56^{* * *}$ & $-9,62^{* * *}$ & $-22,32^{* * *}$ & $-17,03^{* * *}$ \\
\hline Observations & 979 & 979 & 979 & 967 & 979 & 979 & 979 & 967 \\
\hline $\mathrm{N} \times \mathrm{T}$ & $53 \times 20$ & $53 \times 20$ & $53 \times 20$ & $53 \times 20$ & $53 \times 20$ & $53 \times 20$ & $53 \times 20$ & $53 \times 20$ \\
\hline Sargan test (p-value) & $\begin{array}{r}52,06 \\
(0,58)\end{array}$ & $\begin{array}{r}51,74 \\
(0,48)\end{array}$ & $\begin{array}{r}50,94 \\
(0,51)\end{array}$ & $\begin{array}{r}50,34 \\
(0,53)\end{array}$ & $\begin{array}{r}52,01 \\
(0,58)\end{array}$ & $\begin{array}{r}51,69 \\
(0,48)\end{array}$ & $\begin{array}{r}50,85 \\
(0,51)\end{array}$ & $\begin{array}{r}50,37 \\
(0,53)\end{array}$ \\
\hline $\begin{array}{l}\text { First order serial correlation test } \\
\text { (p-value) }\end{array}$ & $\begin{array}{r}-2,85 \\
(0,004)\end{array}$ & $\begin{array}{r}-2,86 \\
(0,004)\end{array}$ & $\begin{array}{r}-2,55 \\
(0,01)\end{array}$ & $\begin{array}{r}-2,72 \\
(0,006)\end{array}$ & $\begin{array}{r}-2,85 \\
(0,004)\end{array}$ & $\begin{array}{r}-2,86 \\
(0,004)\end{array}$ & $\begin{array}{r}-2,55 \\
(0,01)\end{array}$ & $\begin{array}{r}-2,73 \\
(0,006)\end{array}$ \\
\hline $\begin{array}{l}\text { Second order serial correlation } \\
\text { test (p-value) }\end{array}$ & $\begin{array}{l}-0,49 \\
(0,62)\end{array}$ & $\begin{array}{r}-0,51 \\
(0,60)\end{array}$ & $\begin{array}{r}-0,06 \\
(0,95)\end{array}$ & $\begin{array}{r}-0,79 \\
(0,42)\end{array}$ & $\begin{array}{r}-0,49 \\
(0,62)\end{array}$ & $\begin{array}{r}-0,51 \\
(0,60)\end{array}$ & $\begin{array}{l}-0,05 \\
(0,95)\end{array}$ & $\begin{array}{r}-0,79 \\
(0,42)\end{array}$ \\
\hline \multicolumn{9}{|l|}{ Long run coefficients } \\
\hline $\begin{array}{l}\text { Russia's income (ln } G D P_{j, t-1} \text { per } \\
\text { capita) }\end{array}$ & 2,82 & 2,58 & 3,82 & 3,53 & & & & \\
\hline Russia's income $\left(\ln G D P_{j, t-1}\right)$ & & & & & 2,67 & 2,50 & 3,95 & 3,78 \\
\hline Real exchange rate $\left(\ln R E R_{R j, t-1}\right)$ & 1,09 & 0,21 & 0,09 & $-0,11$ & 1,33 & 0,31 & 0,09 & $-0,11$ \\
\hline Import composition $\left(\ln M C_{R j, t-1}\right)$ & & & & 0,47 & & & & 0,50 \\
\hline
\end{tabular}

Note: $\left(^{*}\right]\left[{ }^{* *}\right]$ and $\left\{^{* * *}\right\}$ indicate statistical significance at the $(10 \%)[5 \%]$ and $\{1 \%\}$ levels. 
As in the case of export demand, the estimated income elasticities of bilateral import functions in the short-term are inelastic, and elastic in the long-term. Again, there is no evidence of significant effects of real exchange rate on total imports. The statistical insignificance of exchange rate in the Russian case has been already noted in the empirical literature [Nassif et al., 2016; Tovar-García, 2018].

The rest of control variables agree with findings in the estimation of bilateral export functions. First, Russia is importing more from western and central European countries, and second, the crisis years present a negative impact on bilateral imports (as expected). More interestingly, the coefficient of import composition is positive and statistically significant at the $1 \%$ level. This finding suggests that import composition matters in explaining import performance.

Now, Table 3 shows the estimates of the Russian growth rates in accordance with Thirlwall's law. We obtained several estimates using each of the eight estimated income elasticities of demand for bilateral exports and the eight estimated income elasticities of demand for bilateral imports, for the case of the "strong version». Note that all these estimates are working as robustness checks of the estimated elasticities and growth rates consistent with the balance of payment constraint. Furthermore, we use actual Russian export growth rate, average over the period of analysis $(4,82 \%)$, for estimations of the «weak version» of Thirlwall's law. Later on, we compare our results with the actual economic growth rate of Russia, world growth rate, and the growth rate of the sample countries in our study.

Table 3 .

Estimations of income growth restrictions according to Thirlwall's law

Russian real export growth $(1996-2016)=4,82$

Actual growth rates (1996-2016)

Real GDP per capita

Real GDP

World

Sample countries

Russia

Estimated long-term income elasticities of demand for exports

Regression (1)/(5)

Regression (2)/(6)

Regression (3)/(7)

Regression (4)/(8)

Estimated long-term income elasticities of demand for imports

Regression (1)/(5) 


\begin{tabular}{lrl}
\hline Estimated growth rates according to Thirlwall's law «weak» version & & 1,81 \\
Regression (1)/(5) & 1,71 & 1,93 \\
Regression (2)/(6) & 1,87 & 1,22 \\
Regression (3)/(7) & 1,28 \\
Regression (4)/(8) & 1,26 \\
Estimated growth rates according to Thirlwall's law «strong» version & 1,37 \\
(using GDP of sample countries) & 1,10 \\
Regression (1)/(5) & 1,47 \\
Regression (2)/(6) & 1,23 \\
Regression (3)/(7) & 1,30 \\
Regression (4)/(8) & 1,64 \\
Estimated growth rates according to Thirlwall's law «strong» version (using world GDP) \\
Regression (1)/(5) & 0,58 \\
Regression (2)/(6) & 0,78 \\
Regression (3)/(7) & 0,09 \\
Regression (4)/(8) & 0,82 \\
\hline \hline
\end{tabular}

Note: Data on GDP growth rates from WDI.

First, we can easily observe that the estimated elasticities of import demand are greater than elasticities of export demand. Therefore, we should not expect that Russia could grow more rapidly than the rest of the world or in comparison with the sample countries used to estimate bilateral export and import functions. Moreover, the ratio $\varepsilon / \pi$ approaches the non-price competitiveness of Russia, suggesting that its economy is lagging behind. However, the actual Russian GDP per capita growth rate is greater than the corresponding rate for the sample countries and world GDP in per capita terms.

More interestingly, the estimated growth rate of the Russian income consistent with the balance of payments constrained growth significantly differs from the actual Russian growth rates in levels and in per capita terms. The highest estimates are 1,87\% (per capita) and 2.07\% (levels). These figures are far from the actual Russian GDP per capita $(3,16 \%)$ and in levels $(3,09 \%)$ over the period of analysis. This finding agrees with Nassif et al., (2016), who estimated the income elasticity for exports and imports, respectively, over the years 1995-2013, in 1,08 and 2,23 .

\section{Conclusions}

Since the beginning of the reforming process, the Russian economy has shown relatively high growth rates and strong and persistent current account and trade balance surpluses. These 
facts have motivated the present research trying to analyze the performance of the Russian economy and its relationship with the external sector. In this regard, this paper examined the potential growth rate of Russia according to the demand-side Thirlwall's law approach. In this case, export and import performance imposes limits to economic growth in what is commonly known as the balance of payment constrained growth theory.

Specifically, we studied the balance of payment constraint growth with two pioneering variants. On the one hand, exports and imports functions are estimated using bilateral data of the Russian economy with 53 trade partners in a dynamic panel framework. On the other hand, our estimations include export and import composition accounting for key sectorial effects of high-tech imports and oil and gas exports. In the case of imports, high-tech imports are included following previous literature on Thirlwall's law [Araujo, Lima, 2007; Gouvea, Lima, 2010; Romero et al., 2011]. In the case of exports, the role of natural gas and petroleum is highlighted due to its price inelastic nature [Cooper, 2003; Krichene, 2002; Tovar-García, 2018].

The results showed that the observed rates of growth of the Russian economy have been higher than what is predicted by Thirlwall's law. This paradoxical finding makes sense if we note that the Russian trade balance has been in surplus during the period of study, so the country was not balance-of-payments constrained, probably due to the importance of fuel exports. However, the relevance of export revenues originated from crude oil and gas has been decreasing in the las decade. Therefore, economic growth might not necessarily be constrained by the external sector in Thirlwall's sense. Moreover, this finding agrees with the only previous examination of Thirlwall's approach in the Russian case, developed by Nassif et al., (2016) in an analysis for BRICS countries. By contrast, a model for Russia versus rest of the world did not limit the present research; we estimated a model with a bilateral panel approach. Moreover, we extended the model to account for key sectoral effects adding export and import composition in the estimation of bilateral export and import functions. Thus, our estimates of income elasticities improve accuracy.

What has happened to the Russian economy? The dynamics of the global economy should be contemplated in further analysis. On the one hand, before the 2007-2008 crisis, the world economy was in a process of generalized expansion influenced by the entry into the global dynamics of the Chinese economy and other emerging countries, which pushed up the price of energy, one of the key components in the Russian exports, improving its terms of trade. On the other hand, after the burst of the global financial crisis, the world economy lost dynamism. However, the characteristics of Russian exports (where gas and crude oil are still significant goods in foreign markets) has made them remain a key element in the dynamics of the world economy. Therefore, at least partially, the sectoral composition of the Russian external sector explains why the actual Russian economic growth rates outperform the rates predicted by Thirlwall's law.

However, the global transition toward green energies could have potentially higher effects on the Russian economy, because a relevant proportion of export revenues still depends on fuel exports, whose prices have been recently decreasing. For this reason, the allocation and investment of exports revenues should contemplate future scenarios where carbon-based energy has lost relevance.

Thus, Thirlwall's law is not predicting the actual growth rates of Russia. Nonetheless, the findings highlight the relevance of export and import composition in the performance of the external sector. Consequently, deeper analysis about the effects of export and import composi- 
tion on growth are required (a task for future research). The bilateral panel framework used here has several advantages as multilateral approach. However, due to data limitations, it is not possible to replicate the analysis for each aggregate economic sector and we should recognize that different sectors produce goods with different elasticities. Therefore, a more accurate multisector model with bilateral data is desirable and future research should address this concern.

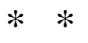

\section{References}

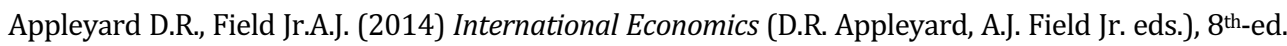
Singapore: McGraw Hill.

Araujo R.A., Lima G.T. (2007) A Structural Economic Dynamics Approach to Balance-of-PaymentsConstrained Growth. Cambridge Journal of Economics, 5 (31), pp. 755-774.

Aristovnik A. (2007) Are Current Account Deficits in Eastern Europe and Former Soviet Union Too High? Transformations in Business \& Economics, 1 (6), pp. 32-53.

Blundell R., Bond S. (1998) Initial Conditions and Moment Restrictions in Dynamic Panel Data

Models. Journal of Econometrics, 1 (87), pp. 115-143.

Britto G., McCombie J.S.L. (2009) Thirlwall's Law and the Long-term Equilibrium Growth Rate: an

Application to Brazil. Journal of Post Keynesian Economics, 1 (32), pp. 115-136.

Clavijo-Cortes P.H., Ros-Bosch J. (2015) La Ley de Thirlwall: una lectura crítica. Investigación Económica, 292 (74), pp. 11-40.

Cooper J.C.B. (2003) Price Elasticity of Demand for Crude Oil: Estimates for 23 Countries. OPEC Review, 1 (27), pp. 1-8.

Gouvea R.R., Lima G.T. (2010) Structural Change, Balance-of-Payments Constraint, and Economic Growth: Evidence from the Multisectoral Thirlwall's Law. Journal of Post Keynesian Economics, 1 (33), pp. 169-204.

Greenaway D., Morgan W., Wright P. (2002) Trade Liberalisation and Growth in Developing Countries. Journal of Development Economics, 1 (67), pp. 229-244.

Grossman G.M., Helpman E. (1990) Trade, Innovation, and Growth. American Economic Review. Papers and Proceedings, 2 (80), pp. 86-91.

Grossman G.M., Helpman E. (1991) Trade, Knowledge Spillovers, and Growth. European Economic Review, 2-3 (35), pp. 517-526.

Hierro Recio L.Á., Atienza Montero P., Hailer A.M. (2018) Desequilibrios comerciales internos y crecimiento económico en la Zona euro. Revista de Economía Mundial, 48, pp. 125-152.

Im K.S., Pesaran M.H., Shin Y. (2003) Testing for Unit Roots in Heterogeneous Panels. Journal of Econometrics, 1 (115), pp. 53-74.

Jeon Y. (2009) Balance-of-Payment Constrained Growth: the Case of China, 1979-2002. International Review of Applied Economics, 2 (23), pp. 135-146.

Krichene N. (2002) World Crude Oil and Natural Gas: a Demand and Supply Model. Energy Economics, 6 (24), pp. 557-576.

Maddala G.S., Wu S. (1999) A Comparative Study of Unit Root Tests with Panel Data and a New Simple Test. Oxford Bulletin of Economics and Statistics, s1 (61), pp. 631-652.

Micco A., Stein E., Ordonez G. (2003) The Currency Union Effect on Trade: Early Evidence from EMU. Economic Policy, 37 (18), pp. 315-356. 
Nassif A., Feijo C.A., Araújo E. (2016) Structural Change, Catching Up and Falling Behind in the BRICS: A Comparative Analysis Based on Trade Patterns and Thirlwall's Law. PSL Quarterly Review, 278 (69), pp. 373-421.

Navoi A.V. (2017) Ustoichivost' balansov mezhdunarodnykh raschetov kak vazhneishaya predposylka finansovoi stabil'nosti [Sustainability of External Balances as an Important Precondition for Financial Stability]. Money and Finance, 6, pp. 66-72. (In Russian)

Palley T.I. (2012) The Rise and Fall of Export-led Growth. Investigación Económica, 280 (71), pp. 141161.

Razmi A. (2005) Balance-of-Payments-Constrained Growth Model: the Case of India. Journal of Post Keynesian Economics, 4 (27), pp. 655-687. 36, pp. 5-46.

Rebelo S. (1992) Growth in Open Economies. Carnegie-Rochester Conference Series on Public Policy,

Romero J.P., McCombie J.S.L. (2016) The Multi-Sectoral Thirlwall's Law: Evidence from 14 Developed European Countries Using Product-level Data. International Review of Applied Economics, 3 (30), pp. 301-325.

Romero J.P., Silveira F., Jayme F.G. (2011) Brazil: Structural Change and Balance-of-PaymentsConstrained Growth. CEPAL Review, December (105), pp. 173-195.

Roodman D. (2009) A Note on the Theme of Too Many Instruments. Oxford Bulletin of Economics and Statistics, 1 (71), pp. 135-158.

Sachs J.D., Warner A. (1995) Economic Reform and the Process of Global Integration. Brookings Papers on Economic Activity, 1 (1995), pp. 1-95.

Thirlwall A.P. (1979) The Balance of Payments Constraints as an Explanation of International Growth Rate Differences. Banca Nazionale del Lavoro Quarterly Review, 128 (32), pp. 45-53.

Thirlwall A.P. (2011) Balance of Payments Constrained Growth Models: Hystory and Overview. PSL Quarterly Review, 259 (64), pp. 307-351.

Thirlwall A.P., Hussain M.N. (1982) The Balance of Payments Constraint, Capital Flows and Growth Rate Differences between Developing Countries. Oxford Economic Papers, 3 (34), pp. 498-510.

Tovar-García E.D. (2018) Does the Share of Crude Petroleum and Natural Gas in Exports Increase Total Exports? The Russian Case. World Economy and International Relations, 6 (62), pp. 30-35.

Tovar-García E.D., Carrasco C.A. (2019) Export and Import Composition As Determinants of Bilateral Trade in Goods: Evidence from Russia. Post-Communist Economies, 4 (31), pp. 530-546.

Wacziarg R., Welch K.H. (2008) Trade Liberalization and Growth: New Evidence. The World Bank Economic Review, 2 (22), pp. 187-231.

Wierts P., Kerkhoff H. Van, Haan J. (2014) De Composition of Exports and Export Performance of Eurozone Countries. Journal of Common Market Studies, 4 (52), pp. 928-941. 